\title{
Pengaruh Kepemilikan Institusional dan Leverage terhadap Nilai Perusahaan
}

\author{
Dikdik Harjadi \\ Nanda Fajarwati \\ Fakultas Ekonomi Universitas Kuningan \\ Email: dikdik.harjadi@yahoo.com \\ Email: nandafajarwati@gmail.com
}

Dewi Fatmasari

Fakultas Syari'ah dan Ekonomi Islam IAIN Syekh Nurjati Cirebon

Email: dewifatmasari73@gmail.com

\begin{abstract}
Abstrak
Penelitian ini bertujuan untuk mengetahui pengaruh kepemilikan institusional dan leverage terhadap nilai perusahaan manufaktur sub sektor tekstil dan garment product di BEI periode 2013-2016.

Metode penelitian yang digunakan dalam penelitian ini adalah metode deskriptif dan verifikatif dengan pendekatan kuantitatif. Populasi dalam penelitian ini adalah seluruh perusahaan manufaktur tekstil dan sub-sektor garmen yang sudah dan masih terdaftar di Bursa Efek Indonesia periode 20132016. Sampel diambil dengan menggunakan metode purposive sampling, dan diperoleh 10 perusahaan. Teknik analisis data yang digunakan panel data regresi.

Hasil penelitian menunjukkan bahwa kepemilikan institusional memiliki pengaruh positif dan signifikan terhadap nilai perusahaan, dibuktikan dengan nilai t sebesar 3,9157 dan signifikansi 0,0004. Leverage berpengaruh positif dan signifikan terhadap nilai perusahaan, terbukti dengan nilai $t$ sebesar 2,7891 dan signifikansi 0,0083. Kepemilikan Institusional dan leverage berpengaruh terhadap nilai perusahaan, terbukti dengan nilai t dalam jumlah 10,0295 dengan signifikansi 0,0003. Nilai adjusted $R^{2}$ diperoleh dalam jumlah 0,3165. Hal ini menunjukkan bahwa kepemilikan institusional dan leverage mempengaruhi nilai perusahaan sebesar 31,65\% dan sisanya sebesar 68,35\% dipengaruhi oleh faktor lain yang tidak diamati dalam penelitian ini.
\end{abstract}

Kata kunci: Kepemilikan Institusional, Leverage, dan Nilai Perusahaan 


\begin{abstract}
The research method that was used in this research was descriptive and verification method with quantitative approach. The population in this research was all manufacturing companies textile and garment sub-sector already and still listed in Indonesia Stock Exchange period 2013-2016. The samples was taken by using purposive sampling method, and acquired 10 companies. The analysis data technique that was used data panel of regression.

The results of research showed that the institutional ownership has a positive and significant effect on firm value, it was proved by the value of $t$ in the amount of 3.915728 and the significance of 0.0004. Leverage has a positive and significant impact on firm value, it was proved by the value of $t$ in the amount of 2.78913 and the significance of 0.0083. Institutional ownership and leverage effects to firm value, it was proved by the value of $t$ in the amount of 10.02950 with significance of 0.000331. The value of adjusted $R^{2}$ acquired in the amount 0.316497. This showed that institutional ownership and leverage influenced firm value in the amount of $31.65 \%$ and remaining in the amount of $68.35 \%$ influenced by other factors that was observed in this research.
\end{abstract}

Keywords: Institutional Ownership, Leverage, and Firm Value 


\section{Pendahuluan}

Pendirian perusahaan memiliki tujuan yang jelas. Tujuan perusahaan yang pertama adalah untuk mencapai keuntungan maksimal atau laba yang sebesar-besarnya. Tujuan perusahaan yang kedua adalah ingin memakmurkan pemilik perusahaan atau para pemilik saham. Sedangkan tujuan perusahaan yang ketiga adalah memaksimalkan nilai perusahaan yang tercermin pada harga sahamnya.

Berinvestasi pada sebuah perusahan diperlukan informasi dan pengetahuan tentang nilai perusahaan. Nilai perusahaan menurut Arifin, (2005) merupakan harga yang bersedia dibayar oleh calon pembeli apabila perusahaan tersebut dijual, semakin tinggi nilai perusahaan semakin besar kemakmuran yang akan diterima oleh pemilik perusahaan. Nilai perusahaan diukur dengan menggunakan Price Book Value (PBV).

PBV yaitu rasio yang menggambarkan seberapa besar pasar menghargai nilai buku saham suatu perusahaan, saham yang memiliki rasio PBV yang besar bisa dikatakan memiliki valuasi yang tinggi (overvalue) sedangkan saham yang memiliki PBV dibawah 1 memiliki valuasi yang rendah (undervalue). (Tjiptono dan Hendry, 2001).

Semakin tinggi PBV berarti perusahaan dapat dikatakan berhasil menciptakan nilai dan kemakmuran pemilik. Menurut Husnan (2001) "Semakin besar nilai PBV semakin tinggi perusahaan dinilai oleh para pemodal relatif dibandingkan dengan dana yang telah ditanamkan di perusahaan". Menurut Prastowo dan Julianti (2005), jika harga pasar berada di bawah nilai bukunya, investor memandang bahwa perusahaan tidak cukup potensial. Bila seorang investor pesimistik atas prospek suatu saham, banyak saham dijual pada harga di bawah nilai bukunya. Sebaliknya jika investor optimistik maka saham dijual dengan harga di atas nilai bukunya.

Berikut adalah nilai PBV perusahaan manufaktur yaitu perusahaan manufaktur sub sektor tekstil \& garment product di Bursa Efek Indonesia periode 2013-2016.

Tabel 1

Nilai Price Book Value Perusahaan Manufaktur Sub Tekstil\&Garment yang Terdaftar di Bursa Efek Indonesia Periode 2013 - 2016

\begin{tabular}{lllllllcr}
\hline No. & Kode & \multicolumn{1}{c}{ Nama Perusahaan } & 2013 & 2014 & 2015 & 2016 & $\begin{array}{c}\text { Rata- rata } \\
\text { Price } \\
\text { Book Value }\end{array}$ \\
\hline $\mathbf{1}$ & ADMG & Polychem Indonesia Tbk & 0.22 & 0.17 & 0.09 & 0.16 & 0.16 \\
$\mathbf{2}$ & ARGO & Argo Pants Tbk & 1.23 & 2.74 & -0.69 & -0.54 & 0.69 \\
$\mathbf{3}$ & CNTX & Century textile Industry Tbk & 1.04 & 2.05 & 2.14 & 1.92 & 1.79 \\
$\mathbf{4}$ & ERTX & Eratex Djaya Tbk & 0.35 & 0.69 & 0.61 & 0.81 & 0.615 \\
$\mathbf{5}$ & ESTI & Ever Shine Tex Tbk & 1.04 & 1.2 & 2.02 & 0.88 & 1.29 \\
$\mathbf{6}$ & HDTX & Panasia Indo Resources Tbk & 0.88 & 0.95 & 2.28 & 1.64 & 1.44 \\
$\mathbf{7}$ & INDR & Indo Rama Synthetic Tbk & 0.18 & 0.14 & 0.12 & 0.14 & 0.15 \\
$\mathbf{8}$ & MYTX & Asia Pacific Investama Tbk & -4.32 & -0.9 & -0.13 & -0.12 & -1.37 \\
\hline
\end{tabular}




\begin{tabular}{llllllll}
\hline $\mathbf{9}$ & PBRX & Pan Brothers Tbk & 1.07 & 1.43 & 1.22 & 1.01 & 1.18 \\
$\mathbf{1 0}$ & POLY & Asia Pasific Fibers Tbk & -0.02 & -0.02 & -0.01 & -0.01 & -0.02 \\
$\mathbf{1 1}$ & RICY & Ricky Putra Globalindol Tbk & 0.29 & 0.29 & 0.26 & 0.24 & 0.27 \\
$\mathbf{1 2}$ & SRIL & Sri Rejeki Isman Tbk & 1.96 & 1.19 & 1.89 & 1.07 & 1.53 \\
$\mathbf{1 3}$ & SSTM & $\begin{array}{l}\text { Sunson Textile Manufacturer } \\
\text { Tbk }\end{array}$ & 0.34 & 0.45 & 0.25 & 1.75 & 0.70 \\
$\mathbf{1 4}$ & STAR & Star Petrochem Tbk & 0.49 & 0.49 & 0.49 & 0.55 & 0.50 \\
$\mathbf{1 5}$ & TFCO & Tifico Fiber Indonesia Tbk & 0.67 & 1.22 & 1.1 & 1.31 & 1.08 \\
$\mathbf{1 6}$ & TRIS & Trisula International Tbk & 1.42 & 1.24 & 0.95 & 0.98 & 1.15 \\
& UNIT & Nusantara Inti Corpora Tbk & 0.08 & 0.1 & 0.08 & 0.11 & 0.09 \\
\hline & & RATA-RATA & 0.41 & 0.79 & 0.75 & 0.7 & \\
\hline
\end{tabular}

Sumber: http://www.idx.co.id/

Berdasarkan tabel dan grafik tersebut dapat diketahui bahwa ratarata nilai PBV Tekstil\&Garment di BEI tahun 2013-2016 menunjukkan sebagian besar (10 perusahaan) data dibawah satu maka nilai perusahaan termasuk tidak baik. Hal ini merupakan masalah berupa kurang maksimalnya nilai perusahaan Tekstil\&Garment di BEI tahun 2013-2016. Adanya masalah ini dapat berdampak terhadap menurunya minat investor untuk menanamkan dananya pada perusahaan.

Rizqia et al. (2013) menyatakan faktor-faktor yang secara prinsip memengaruhi nilai perusahaan adalah leverage, ukuran perusahaan, dan profitabilitas. Menurut penelitian Isti'adah (2015) faktor-faktor yang mempengaruhi nilai perusahaan adalah kepemilikan manajerial, kepemilikan institusional, komite audit, dan kualitas laba. Namun dalam penelitian ini hanya akan membahas dua faktor yang dianggap dapat memengaruhi nilai perusahaan yaitu kepemilikan institusional dan leverage.

Kepemilikan institusional adalah proporsi kepemilikan saham pada akhir tahun yang dimiliki oleh lembaga, seperti asuransi, bank atau institusi lain (Tarjo, 2008).
Kepemilikan institusional memiliki arti penting dalam memonitor manajemen. Adanya kepemilikan oleh institusional akan mendorong peningkatan pengawasan yang lebih optimal. Semakin tinggi kepemilikan institusional maka akan mengurangi perilaku opportunistic manajer yang dapat mengurangi agency cost yang diharapkan akan meningkatkan nilai perusahaan (Wahyudi dan Pawestri, 2006). Menurut Shleifer dan Vishny (dalam Haruman, 2008), jumlah pemegang saham yang besar (large shareholders) mempunyai arti penting dalam memonitor perilaku manajer dalam perusahaan.

Menurut Faizal (2004), perusahaan dengan kepemilikan institusional yang besar mengindikasikan kemampuannya untuk memonitor manajemen. Semakin besar kepemilikan institusional maka semakin efisien pemanfaatan aktiva perusahaan dan diharapkan juga dapat bertindak sebagai pencegahan terhadap pemborosan yang dilakukan oleh manajemen.

Untuk memperoleh sumber pendanaan, perusahaan dapat menggunakan hutang (leverage) untuk memperoleh modal guna mendapatkan 
keuntungan yang lebih tinggi. Leverage Menurut Wiagustina (2010), bahwa perusahaan dapat menggunakan hutang (leverage) untuk memperoleh modal guna mendapatkan keuntungan yang lebih tinggi. Leverage merupakan kemampuan perusahaan untuk melunasi kewajiban finansial perusahaan baik jangka pendek maupun panjang. Leverage dapat dikatakan bahwa suatu rasio keuangan yang mengukur seberapa banyak perusahaan dibiayai dengan hutang. Jadi hutang merupakan tanda atau sinyal positif untuk meningkatkan nilai perusahaan dimata investor (Hanafi, 2011). Pengelolaan leverage sangatlah penting, sebab keputusan dalam penggunaan hutang yang tinggi dapat meningkatkan nilai perusahaan karena adanya pengurangan atas pajak penghasilan.

Berdasarkan latar belakang, masalah yang dapat dirumuskan:

1. Apakah kepemilikan institusional dan leverage berpengaruh terhadap nilai perusahaan manufaktur sub sektor tekstil\&garment product di BEI periode 2013-2016?

2. Bagaimana pengaruh kepemilikan institusional terhadap nilai perusahaan sub sektor tekstil\&garment product di BEI periode 2013-2016?

3. Bagaimana pengaruh leverage terhadap nilai perusahaan sub sector tekstil\&garment product di BEI periode

2013-2016?

\section{Gambar 1 \\ Paradigma Penelitian}

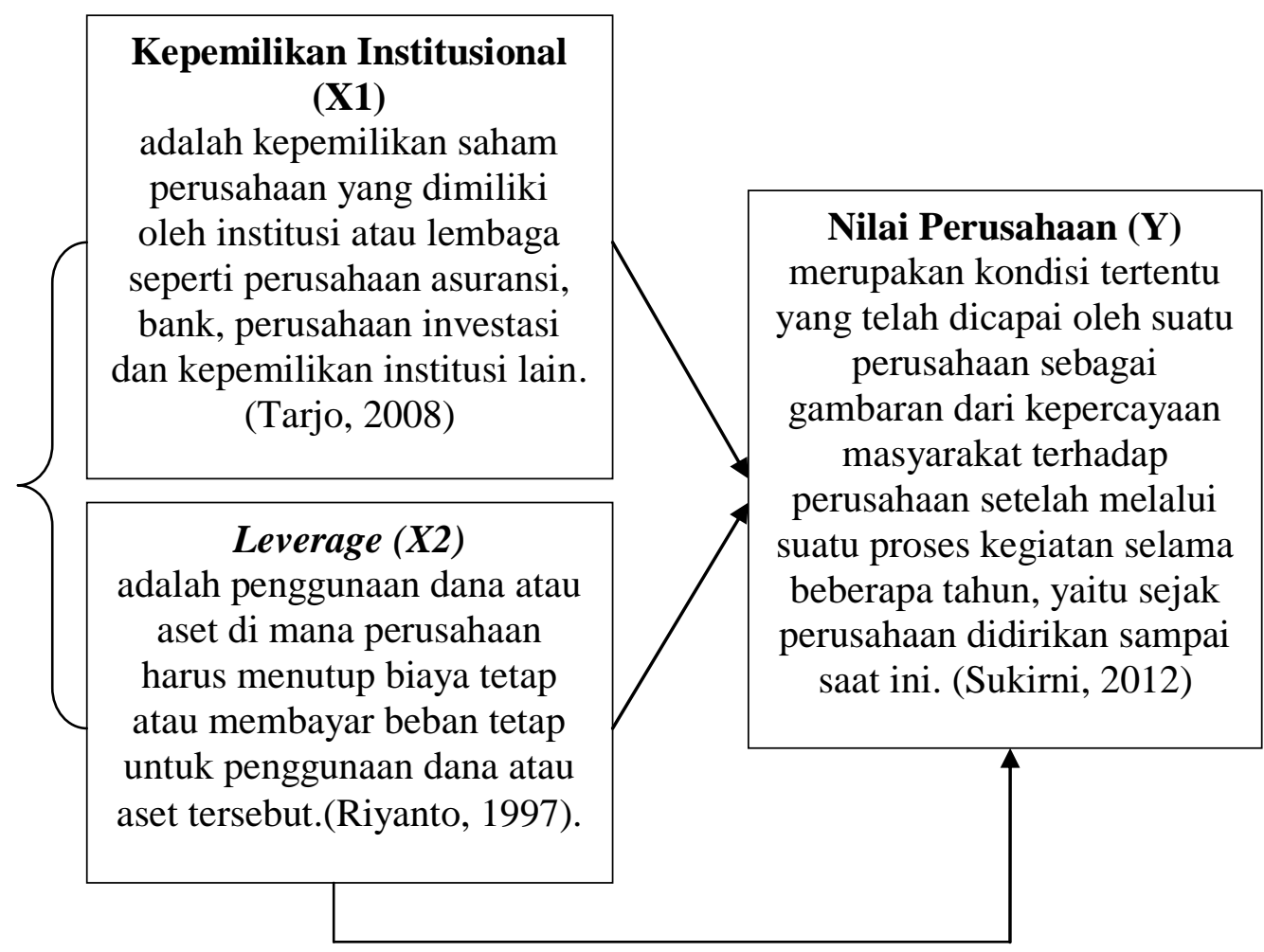


Berdasarkan teori yang telah dipaparkan, hipotesis penelitian ini sebagai berikut:

$\mathrm{H}_{1}$ : Kepemilikan Institusional dan leverage berpengaruh terhadap nilai perusahaan.

$\mathrm{H}_{2}$ : Kepemilikan Institusional berpengaruh positif terhadap nilai Perusahaan

$\mathrm{H}_{3}$ : Leverage berpengaruh positif terhadap nilai perusahaan.

\section{Metode Penelitian}

Metode penelitian yang digunakan dalam penelitian ini adalah metode deskriptif dan verifikatif dengan pendekatan kuantitatif. Menurut Sugiyono (2012) "Metode deskriptif adalah metode yang digunakan untuk menggambarkan atau menganalisis suatu hasil penelitian tetapi tidak digunakan untuk membuat kesimpulan yang lebih luas".

Metode verifikatif adalah suatu metode yang bertujuan untuk menggambarkan hubungan atau pengaruh antara variabel dengan cara mengumpulkan data, mengolah, menganalisis dan mengintreprestasikan data dalam pengujian hipotesis statistik (Sugiyono, 2010).

Populasi dalam penelitian ini adalah perusahaan manufaktur sub sektor tekstil dan garment products yang terdaftar di BEI dalam kurun waktu tahun 2013-2016 yaitu 17 perusahaan. Data diperoleh dari sumber data sekunder, yaitu Indonesian Capital Market Directory (ICMD).

Teknik pengambilan sampel yang digunakan dalam penelitian ini adalah metode purposive sampling, yaitu sample yang ditarik dengan menggunakan kriteria tertentu, yaitu:

a. Perusahaan manufaktur yang mempublikasikan laporan keuangan dari tahun 2013-2016.

b. Perusahaan yang mempublikasikan laporan keuangan yang telah diaudit dengan menggunakan tahun buku yang berakhir pada tanggal 31 Desember.

c. Perusahaan yang rata-rata nilai perusahaannya dibawah 1 .

Berdasarkan kriteria tersebut maka dapat ditentukan perusahaan yang dijadikan sampel dalam penelitian ini seperti pada tabel berikut:

Tabel 2

Perusahaan Manufaktur Sub Sektor Textile dan Garment Product yang Terdaftar di Bursa Efek Indonesia Tahun 2013 - 2016

\begin{tabular}{clcccl}
\hline No. & \multicolumn{1}{c}{ Nama Perusahaan } & 1 & 2 & 3 & \multicolumn{1}{c}{ Ket. } \\
\hline $\mathbf{1}$ & Polychem Indonesia Tbk & $\checkmark$ & $\checkmark$ & $\checkmark$ & Sampel \\
$\mathbf{2}$ & Argo Pants Tbk & $\checkmark$ & $\checkmark$ & $\checkmark$ & Sampel \\
$\mathbf{3}$ & Century textile Industry Tbk & $\checkmark$ & $\checkmark$ & x & Bukan Sampel \\
$\mathbf{4}$ & Eratex Djaya Tbk & $\checkmark$ & $\checkmark$ & $\checkmark$ & Sampel \\
$\mathbf{5}$ & Ever Shine Tex Tbk & $\checkmark$ & $\checkmark$ & x & Bukan Sampel \\
$\mathbf{6}$ & Panasia Indo Resources Tbk & $\checkmark$ & $\checkmark$ & x & Bukan Sampel \\
$\mathbf{7}$ & Indo Rama Synthetic Tbk & $\checkmark$ & $\checkmark$ & $\checkmark$ & Sampel \\
$\mathbf{8}$ & Asia Pacific Investama Tbk & $\checkmark$ & $\checkmark$ & $\checkmark$ & Sampel \\
\hline
\end{tabular}




\begin{tabular}{clcccl}
\hline $\mathbf{9}$ & Pan Brothers Tbk & $\checkmark$ & $\checkmark$ & x & Bukan Sampel \\
$\mathbf{1 0}$ & Asia Pasific Fibers Tbk & $\checkmark$ & $\checkmark$ & $\checkmark$ & Sampel \\
$\mathbf{1 1}$ & Ricky Putra Globalindol Tbk & $\checkmark$ & $\checkmark$ & $\checkmark$ & Sampel \\
$\mathbf{1 2}$ & Sri Rejeki Isman Tbk & $\checkmark$ & $\checkmark$ & x & Bukan Sampel \\
$\mathbf{1 3}$ & Sunson Textile Manufacturer Tbk & $\checkmark$ & $\checkmark$ & $\checkmark$ & Bukan Sampel \\
$\mathbf{1 4}$ & Star Petrochem Tbk & $\checkmark$ & $\checkmark$ & $\checkmark$ & Sampel \\
$\mathbf{1 5}$ & Tifico Fiber Indonesia Tbk & $\checkmark$ & $\checkmark$ & x & Bukan Sampel \\
$\mathbf{1 6}$ & Trisula International Tbk & $\checkmark$ & $\checkmark$ & x & Bukan Sampel \\
$\mathbf{1 7}$ & Nusantara Inti Corpora Tbk & $\checkmark$ & $\checkmark$ & $\checkmark$ & Sampel \\
\hline
\end{tabular}

Berdasarkan tabel kriteria sampel tersebut, maka diperoleh 10 sampel perusahaan tekstil\&garment products, sebagai berikut:

1. Polychem Indonesia Tbk

2. Argo Pants Tbk

3. Eratex Djaya Tbk

4. Indo Rama Synthetic Tbk

5. Asia Pacific Investama Tbk

6. Asia Pasific Fibers Tbk

7. Ricky Putra Globalindol Tbk

8. Sunson Textile Manufacturer Tbk

9. Star Petrochem Tbk

10. Nusantara Inti Corpora Tbk

Data yang digunakan dalam penelitian ini adalah data sekunder. Sedangkan metode yang digunakan adalah metode studi pustaka, yaitu dengan melakukan telaah pustaka, eksplorasi dan mengkaji berbagai literatur pustaka seperti majalah, jurnal dan sumber-sumber lain yang berkaitan dengan penelitian. Setelah mendapatkan data-data yang dibutuhkan dalam penelitian ini, peneliti akan melakukan serangkaian tahap untuk menghitung dan mengolah data-data tersebut, agar dapat mendukung hipotesis yang telah diajukan.

Metode yang digunakan untuk menganalisis data dalam penelitian ini menggunakan analisis statistik Regresi
Data Panel untuk mengukur pengaruh kepemilikan institusional dan leverage terhadap nilai perusahaan. Hal ini dilakukan karena data penelitian ini merupakan data panel. Data panel merupakan gabungan dari data cross section dan deret waktu (time series) sehingga berimplikasi terhadap jumlah dalam data penel ada tiga macam teknik yang dapat di gunakan yaitu model common effect, fixed effect, dan random effect.

Nilai koefisien determinasi adalah antara nol dan satu, dimana nilai $\mathrm{R}^{2}$ yang kecil atau mendekati nol berarti kemampuan variabel-variabel independen dalam menjelaskan variabel dependen amat terbatas, namun jika nilai $\mathrm{R}^{2}$ yang besar atau mendekati satu berarti variabel-variabel independen memberikan hampir semua informasi yang dibutuhkan untuk memprediksi variasi variabel dependen (Ghozali, 2011).

Uji simultan (Uji F) ini bertujuan untuk mengetahui apakah variabel independen secara simultan berpengaruh signifikan terhadap variabel dependen. Uji $F$ digunakan untuk menguji signifikansi pengaruh variabel $X_{1}$ (kepemilikan intitusional), $\mathrm{X}_{2}$ (leverage), secara simultan atau bersama-sama terhadap variabel terikat yaitu Y (Nilai Perusahaan). Kriteria 
penerimaan dan penolakan Hipotesis yaitu Kriteria uji yang digunakan adalah jika $F_{\text {hitung }}>F_{\text {tabel }}$ maka Ho ditolak dan $\mathrm{Ha}$ diterima dan jika $F_{\text {hitung }}<F_{\text {tabel }}$ maka Ho diterima dan $\mathrm{Ha}$ ditolak.

Uji parsial (uji t) digunakan untuk menentukan apakah variabel $\mathrm{X}_{1}$ (Kepemilikan institusional) dan $\mathrm{X}_{2}$ (Leverage) berpengaruh secara parsial terhadap variabel terikat yaitu Y (Nilai Perusahaan).

\section{Hasil dan Pembahasan}

Berdasarkan pengujian ketiga model regresi data panel dengan menggunakan uji chow, output eviews menunjukan bahwa model common Effect lebih baik daripada model Fixed Effect dan Random Effect.

Hasil estimasi model Common Effect dapat dilihat pada table berikut:

Tabel 3

Hasil Estimasi dengan Model Common Effect

\begin{tabular}{|c|c|c|c|c|}
\hline \multicolumn{3}{|c|}{ Dependent Variable: Nilai_Perusahaan } & & \\
\hline \multicolumn{3}{|c|}{ Method: Panel Least Squares } & & \\
\hline \multicolumn{5}{|c|}{ Date: 07/26/17 Time: $14: 44$} \\
\hline \multicolumn{5}{|l|}{ Sample: 20132016} \\
\hline \multicolumn{5}{|l|}{ Periods included: 4} \\
\hline \multicolumn{5}{|c|}{ Cross-sections included: 10} \\
\hline \multicolumn{5}{|c|}{ Total panel (balanced) observations: 40} \\
\hline Variable & Coefficient & Std. Error & t-Statistic & Prob. \\
\hline Nilai_Perusahaan & -3.704897 & 1.338129 & -2.768714 & 0.0087 \\
\hline $\begin{array}{c}\text { Kepemilikan_Institusi } \\
\text { onal }\end{array}$ & 0.138388 & 0.035341 & 3.915728 & 0.0004 \\
\hline Leverage & 0.039023 & 0.013991 & 2.789137 & 0.0083 \\
\hline R-squared & 0.351548 & \multicolumn{2}{|c|}{ Mean dependent var } & 0.008250 \\
\hline Adjusted R-squared & 0.316497 & \multicolumn{2}{|c|}{ S.D. dependent var } & 1.164712 \\
\hline S.E. of regression & 0.962917 & \multicolumn{2}{|c|}{ Akaike info criterion } & 2.834339 \\
\hline Sum squared resid & 34.30671 & \multicolumn{2}{|c|}{ Schwarz criterion } & 2.961004 \\
\hline Log likelihood & -53.68677 & \multicolumn{2}{|c|}{ Hannan-Quinn criter. } & 2.880137 \\
\hline F-statistic & 10.02950 & \multicolumn{2}{|c|}{ Durbin-Watson stat } & 1.773536 \\
\hline Prob(F-statistic) & 0.000331 & & & \\
\hline
\end{tabular}

Sumber:Output Eviews 9.0

Berdasarkan hasil estimasi tabel diatas maka dapat diketahui persamaan model common effect sebagai berikut:

$$
\mathbf{Y}=-3.704897+0.138388 \mathrm{X}_{1}+0.039023 \mathrm{X}_{2}
$$


Persamaan tersebut mempunyai makna sebagai berikut:

a. Nilai konstanta pada persamaan sebesar -3,704897 menunjukan bahwa variabel independen kepemilikan institusional dan leverage dianggap bernilai 0 , maka nilai perusahaan sebesar 3,704897.

b. Koefisien regresi kepemilikan institusional $\quad 0,138388$ menunjukkan adanya pengaruh yang positif antara kepemilikan institusional terhadap nilai perusahaan. Artinya, apabila variabel bebas lain nilainya tetap dan kepemilikan institusional mengalami kenaikan sebesar $1 \%$ maka nilai perusahaan akan

mengalami peningkatan sebesar $0,138388 \%$.

c. Koefisien regresi leverage sebesar 0,039023 menunjukkan adanya pengaruh yang positif antara leverage terhadap nilai perusahaan. Artinya, apabila variablebebas lain nilainya tetap dan leverage mengalami kenaikan sebesar $1 \%$ maka nilai perusahaan akan mengalami peningkatan sebesar $0,039023 \%$.

\section{Hasil Uji Koefisien Determinasi $\left(\mathbf{R}^{2}\right)$}

Berdasarkan hasil analisis maka besarnya pengaruh variabel kepemilikan institusional dan leverage terhadap nilai perusahaan dapat dilihat pada tabel dibawah ini:

Tabel 4

Hasil Uji Koefisien Determinasi $\left(\mathbf{R}^{2}\right)$ dan Uji F

\begin{tabular}{|l|r|l|r|}
\hline \hline R-squared & 0.351548 & Mean dependent var & 0.008250 \\
\hline Adjusted R-squared & 0.316497 & S.D. dependent var & 1.164712 \\
\hline S.E. of regression & 0.962917 & Akaike info criterion & 2.834339 \\
\hline Sum squared resid & 34.30671 & Schwarz criterion & 2.961004 \\
\hline Log likelihood & & Hannan-Quinn & \\
\hline F-statistic & -53.68677 & criter. & 2.880137 \\
\hline Prob(F-statistic) & 10.02950 & Durbin-Watson stat & 1.773536 \\
\hline
\end{tabular}

Sumber:Output Eviews 9.0

Berdasarkan pada tabel 4 di atas dapat dilihat bahwa nilai adjusted Rsquared sebesar 0,316497. Nilai ini berarti variabel kebijakan hutang dan kepemilikan manajerial secara simultan berpengaruh terhadap nilai perusahaan sebesar 31,65\%. Sisanya merupakan 
pengaruh dari variabel lain di luar variabel yang diteliti sebesar 68,35\%.

\section{Pengujian Hipotesis}

Berdasarkan hasil uji $\mathrm{F}$ pada tabel 4 terlihat bahwa nilai $F_{\text {hitung }}$ sebesar 10,02950 dengan tingkat signifikansi 0,000331 dan nilai $F_{\text {tabel }}$ dengan tingkat signifikansi 0,$05 ; \mathrm{df}_{1}$ (jumlah variabel-1)=3-1=2 dan $\mathrm{df}_{2}(\mathrm{n}$ - $\mathrm{k}-1)=40-2-1=37$, hasil diperoleh untuk $F_{\text {tabel }}$ sebesar 3,25. Maka dapat dilihat bahwa $F_{\text {hitung }}>F_{\text {tabel }}(10,02950>3,25)$, artinya $\mathrm{H}_{0}$ ditolak dan $\mathrm{H}_{\mathrm{a}}$ diterima. Ini berarti kepemilikan institusional dan leverage berpengaruh secara simultan dan signifikan terhadap nilai perusahaan. Berikut hasil pengujian signifikansi $t$ yang diperoleh dari model ini:

Tabel 5

Hasil Uji t

\begin{tabular}{|c|r|r|r|r|}
\hline Variable & Coefficient & Std. Error & t-Statistic & Prob. \\
\hline Nilai_perusahaan & -3.704897 & 1.338129 & -2.768714 & 0.0087 \\
\hline Kepemilikan_institusional & 0.138388 & 0.035341 & 3.915728 & 0.0004 \\
\hline Leverage & 0.039023 & 0.013991 & 2.789137 & 0.0083 \\
\hline
\end{tabular}

Sumber :Output Eviews ver. 9.0

Berdasarkan tabel 5, pengujian pengaruh variabel kepemilikan institusional terhadap nilai perusahaan diperoleh $t_{\text {hitung }}$ sebesar 3,915728 dan nilai $t_{\text {tabel }}$ pada signifikanya 0,05 dan $\mathrm{df}(\mathrm{n}-\mathrm{k}-1)=40-2-1=37$ diperoleh sebesar 1,68709 dan nilai signifikannya sebesar 0,0004. Jika dibandingkan nilai $t_{\text {hitung }}$ dengan $t_{\text {tabel }}$, maka $t_{\text {hitung }}>t_{\text {tabel }}(3,915728>1,68709)$ maka $\mathrm{H}_{0}$ ditolak dan $\mathrm{H}_{\mathrm{a}}$ diterima, sehingga dapat disimpulkan bahwa kepemilikan institusional berpengaruh positif dan signifikan terhadap nilai perusahaan.

Pengujian pengaruh variabel leverage terhadap nilai perusahaan diperoleh $t_{\text {hitung }}$ sebesar 2,789137dan nilai $t_{\text {tabel }}$ pada signifikanya 0,05 dan df $(n-k-1)=40-2-1=37$ diperoleh sebesar 1,68709 dan nilai signifikannya sebesar 0,0083. Jika dibandingkan nilai $t_{\text {hitung }}$ dengan $t_{\text {tabel }}$, maka $t_{\text {hitung }}>t_{\text {tabel }}(2,78913>1,68709)$ maka $\mathrm{H}_{0}$ ditolak dan $\mathrm{H}_{\mathrm{a}}$ diterima, sehingga dapat disimpulkan bahwa leverage berpengaruh positif dan signifikan terhadap nilai perusahaan.

\section{Pembahasan}

\section{Pengaruh Kepemilikan Intitusional dan}

\section{Leverage Terhadap Nilai Perusahaan}

Berdasarkan hasil dari analisis regresi dalam penelitian ini diketahui bahwa kepemilikan institusional dan leverage berpengaruh secara simultan terhadap nilai perusahaan pada perusahaan textile and garment product yang terdaftar di Bursa Efek Indonesia. Hal tersebut dapat dijadikan pedoman bagi manajemen perusahaan untuk memprediksi nilai perusahaan dan membantu dalam pengambilan keputusan untuk 
berinvestasi. Hal ini dapat dilakukan dengan menganalisa laporan keuangan, karena dapat diperkirakan keadaan atau posisi dan arah perusahaan.

Hal ini berarti kepemilikan institusional dan leverage mempengaruhi nilai perusahaan. Pengaruh yang signifikan tersebut menunjukan bahwa uji hipotesis variabel kepemilikan institusional dan leverage secara simultan memiliki pengaruh yang signifikan terhadap nilai perusahaan sehingga dalam penelitian ini dapat digeneralisasikan atau diberlakukan secara umum pada anggota oplasi keseluruhan.

Hasil penelitian ini sejalan dengan penelitian yang dilakukan oleh Pratiwi, et al. (2016) yang menyatakan bahwa kepemilikan institusional dan leverage secara simultan berpengaruh terhadap nilai perusahaan.

\section{Pengaruh Kepemilikan Intitusional terhadap Nilai Perusahaan}

Berdasaran Uji parsial (t-hitung) pengaruh kepemilikan institusional terhadap nilai perusahaan diperoleh koefisien regresi $\mathrm{t}_{\text {hitung }}$ sebesar 3,915728 dan nilai $\mathrm{t}_{\text {tabel }}$ pada signifikansi 0,05 dan df $(n-k-1)=40-2-1=37$ diperoleh sebesar 1,68709. Jika dibandingkan nilai $t_{\text {hitung }}$ dengan $t_{\text {tabel }}$, maka $t_{\text {hitung }}>t_{\text {tabel }}(3,915728>1,68709)$ maka $\mathrm{H}_{0}$ ditolak dan $\mathrm{H}_{\mathrm{a}}$ diterima, sehingga dapat disimpulkan kepemilikan institusional berpengaruh positif dan signifikan terhadap nilai perusahaan pada perusahaan textile and garment product.

Hasil ini sejalan dengan penelitian sebelumnya yang dilakukan penelitian yang dilakukan Warapsari dan Suaryana (2016) menunjukkan bahwa kepemilikan institusional berpengaruh positif dan signifikan pada nilai perusahaan, hal ini sama dengan hasil penelitian Sukirni (2012) dan Pratiwi et al. (2016) yang menyatakan bahwa kepemilikan institusional berpengaruh positif dan signifikan terhadap nilai perusahaan.

\section{Pengaruh Leverage terhadap Nilai \\ Perusahaan}

Berdasarkan hasil analisis regresi hasil regresi membuktikan bahwa leverage berpengaruh signifikan dan memiliki arah yang positif terhadap nilai perusahaan. Terlihat pada Uji parsial (t-hitung) pengaruh variabel leverage terhadap nilai perusahaan diperoleh $t_{\text {hitung }}$ sebesar 2,78913 dan nilai $\mathrm{t}_{\text {tabel }}$ pada signifikansi 0,05 dan df (n-k$1)=40-2-1=37$ diperoleh sebesar 1,68709. Jika dibandingkan nilai $t_{\text {hitung }}$ dengan $t_{\text {tabel }}$, maka $t_{\text {hitung }}>t_{\text {tabel }}(2,78913>1,68709)$ maka $\mathrm{H}_{0}$ diterima dan $\mathrm{H}_{\mathrm{a}}$ ditolak, sehingga dapat disimpulkan bahwa leverage berpengaruh positif dan signifikan terhadap nilai perusahaan. Hasil ini sejalan dengan penelitian sebelumnya yang dilakukan oleh Kouki dan Hatemn (2011), Angga dan Wiksuana (2016), serta Gill dan Obradovich (2012).

Berdasarkan hasil penelitian tersebut menunjukkan bahwa semakin tinggi nilai leverage maka nilai perusahaan juga akan semakin meningkat. Hasil pengujian senada dengan teori yang dikemukakan Wiagustina (2010), bahwa perusahaan dapat menggunakan hutang (leverage) untuk memperoleh modal guna mendapatkan keuntungan yang lebih tinggi.

\section{Penutup}

Berdasarkan hasil penelitian, analisis dan pembahasan yang telah dilakukan dan diuraikan, maka dapat ditarik kesimpulan sebagai berikut:

1. Kepemilikan intitusional dan leverage secara bersama-sama berpengaruh signifikan terhadap nilai perusahaan manufaktur yang terdaftar di Bursa Efek Indonesia tahun 2013-2016. 
Artinya, untuk meningkatkan nilai perusahaan harus memperhatikan variabel kepemilikan institusional $\left(\mathrm{X}_{1}\right)$ dan leverage $\left(\mathrm{X}_{2}\right)$ untuk dijadikan pedoman bagi manajemen perusahaan untuk memprediksi nilai perusahaan dan membantu dalam pengambilan keputusan untuk berinvestasi.

2. Kepemilikan Institusional berpengaruh positif dan signifikan terhadap nilai perusahaan manufaktur yang terdaftar di Bursa Efek Indonesia tahun 20132016, artinya jika kepemilikan institusional meningkat maka nilai perusahaan pun ikut meningkat.

3. Leverage secara parsial berpengaruh positif dan signifikan terhadap nilai perusahaan manufaktur yang terdaftar di Bursa Efek Indonesia tahun 20132016, artinya semakin tinggi nilai leverage maka semakin tinggi pula nilai perusahaan.

\section{Daftar Pustaka}

Angga Pratama, I G B dan I G B Wiksuana. 2016. Pengaruh Ukuran Perusahaan dan Leverage Terhadap Nilai Perusahaan Dengan Profitabilitas Sebagai Variabel Mediasi. E-Jurnal Manajemen Unud.5(2).h: 1338-1367.

Brigham, Eugene F dan Houston. 2006. Fundamental of Financial Management: Dasar-Dasar Manajemen Keuangan. Edisi 10. Jakarta: Salemba Empat

Arifin, 2005, Teori Keuangan dan Pasar Modal, Ekonesia, Yogyakarta

Arosa, B., Iturralde, T., \& Maseda, A. (2009). Ownership Structure, Insiders Ownership and Firm Performance in Spanish Non-Listed Firms. https://doi.org/10.2139/ssrn.1505308
Brigham and Houston, 2000, Manajemen Keuangan Terjemahan, Penerbit Erlangga, Jakarta

Blair, M. M. (1995). Ownership and control: rethinking corporate governance for the twenty-first century. Challenge, 39(1). Retrieved from http://www.jstor.org/stable/40721671

Brealey, et. Al. 2007. Dasar-dasar manajemen keuangan. Jakarta: Penerbit Erlangga

Barnae, Amir dan RubinAmir, 2005. Corporate Social Responsibility as a Conflict Between Shareholders. www.ssrn.com

Cheng, Ming-Chang and Zuwei-Ching Tzeng. 2011. The Effect of Leverage on Firm Value and How The Firm Financial Quality Influence on This Effect. World Journal of Management. 3(2): pp: 30-53.

Cho, D.-S., \& Kim, J. (2007). Outside Directors, Ownership Structure and Firm Profitability in Korea. Corporate Governance: An International Review, 15(2), 239-250. https://doi.org/10.1111/j.14678683.2007.00557.x

Darmadji Tjiptono \& Hendy M Fakhrudin, 2011, Pasar Modal di Indonesia Edisi 3, Salemba Empat, Jakarta.

Demsetz , H. (1983). The Structure of Ownership and the Theory of the Firm. Journal of Law and Economics, 26(2),375-390. https://doi.org/10.1086/467041

Dyah, Reny, dan Denis, Priatinah. 2012. Pengaruh Good Corporate Governance Dan Pengungkapan Corporate Social Responsibility Terhadap Nilai Perusahaan (Studi Empiris Pada Perusahaan Yang Terdaftar Di Bursa Efek Indonesia Periode 2007-2010). Jurnal Nominal Volume 1 No.1.

Eelderink, G. (2014). Effect of ownership structure on firm performance. Retrieved from http://purl.utwente.nl/essays/65629 
Faizal, 2004, Analisis Agency Cost, Struktur Kepemilikan dan Mekanisme Corporate Governance, Simposium Nasional Akuntansi VII, Denpasar Bali.

Febrianti, Meiriska. 2012. Faktor-faktor Yang Mempengaruhi Nilai Perusahaan pada Industri Pertambangan di Bursa Efek Indonesia. Jurnal Bisnis dan Akuntansi. 14((2). h: 141-156.

Financial Reporting Council. (2014). The UK Corporate Governance Code. London.

G. M. (1995). Equity ownership structure, leverage and productivity: empirical evidence from Japan. Pacific-Basin Finance Journal, 3(2), 241-255.

Ghozali, Imam. 2011. Aplikasi Analisis Multivariate Dengan Program SPSS. Semarang: Badan Penerbit Universitas Diponegoro.

Gorton, G., \& Schmid, F. A. (1996). Universal Banking and the Performance of German Firms. Journal of Financial Economics. https://doi.org/10.3386/w5453

Gill, Amarjit dan Obradovich, John. 2012. The Impact of Corporate Governance and Financial Leverage on the Value of American Firms. International Research Journal of Finance and Economics. ISSN 14502887 Issue 91

Hanafi, Mamduh M. 2011. Manajemen Keuangan. Yogyakarta: BPFE.

Harris, M., \&Raviv, A. (1991). The Theory of Capital Structure. The Journal of Finance, 46(1), 297-355. https://doi.org/10.1111/j.15406261.1991.tb03753.x

Hill, C. W., \& Snell, S. A. (2006). External control, corporate strategy, and firm performance in research-intensive industries. Strategic Management Journal, 9(6), 577-590. https://doi.org/10.1002/smj.42500906 05
Himmelberg, C. P., Hubbard, R., \& Palia, D. (1999). Understanding the determinants of managerial ownership and the link between ownership and performance. Journal of Financial Economics, 53(3), 353384.https://doi.org/10.1016/S0304405X(99)00025-2

Hitt, M. A., Ireland, R. D., \& Hoskisson, R. E. (2006). Strategic Management Concepts and Cases: Competitivnessand Globalization. South-Western College.

Hitt, M., Duane, R., \&Hoskisson, R. (2006). Strategic Management: Concepts and Cases. Cengage Learning.

Husnan Suad, 2002, Manajemen Keuangan Teori dan Praktek, Yayasan Badan Penerbit Gajah Mada Yogyakarta.

Haruman, Tendi. (2007). Pengaruh Keputusan Keuangan dan Kepemilikan Institusional Terhadap Nilai Perusahaan. PPM National Conference on Management Research"Manajemen di Era Globalisasi”. Hal 1-20. Bandung.

Ismail, A. (2009). Private Equity and Venture Capital in Emerging Markets: A Case Study of Egypt and the MENA region.

Isti'adah, Ummi., 2015, Faktor-Faktor Yang Mempengaruhi Nilai Perusahaan Pada Perusahaan Manufaktur, Jurnal Nominal, Vol. 4, No. 2, hal. 57-72.

I Gusti Bagus Angga Pratama, I Gusti Bagus Wiksuana. 2016. Pengaruh Ukuran Perusahaan dan Leverage terhadap Nilai Perusahaan dengan Profitabilitas sebagai variable Mediasi (Vol. 5, No. 2, 2016: 13381367)

Juhandi, et al., 2013, The Effects of Internal Factors and Stock Ownership Structure on Dividend Policy on Company's Value. International Journal of Business and Management Invention. Vol. 2 p 06-18.

Kouki, Mondher dan Hatem bin Said. 2011. Does Manageent Ownership explain 
theeffect of Leverage on Firm Value? An Analisys of French Listed Firm. Journal of Bussiness studies quartelly Vol 3(1) Hal 169186

Ni Luh Putu \& Wiagustini, 2010, DasarDasar Manajemen Keuangan, Udayana University Press, Denpasar.

Nabela, Yoandhika. 2012. Pengaruh Kepemilikan Institusional, Kebijakan Dividen Dan Profitabilitas Terhadap Kebijakan Hutang Pada PerusahaanProperti Dan Real Estate Di Bursa Efek Indonesia. Jurnal Manajemen, Volume 01, pp. 1-8.

Pratiwi, et al. 2016. Pengaruh Kepemilikan Manajerial, Kepemilikan Institusional, dan Leverage terhadap Nilai Perusahaan. e-Proceeding of Management : Vol.3, No.3 December 2016 | Page 3191. Universitas Telkom

Dwi Prastowo dan Rifka Julianti. 2005. Analisis Laporan Keuangan. Konsep dan Aplikasi. Edisi Kedua. UPP AMP YKPN, Yogyakarta

Ownership, Financial Leverage, Profitability, Firm Size, and Investment Opportunity on Dividend Policy and Firm Value. Research Journal of Finance and Accounting. 4 (11), h: 120-130

Sukirni, Dwi, 2012, Kepemilikan Manajerial,

Kepemilikan Institusional, Kebijakan Deviden dan Kebijakan Hutang: Analisis Terhadap Nilai Perusahaan, Accounting Analysis Journal Vo.2 No.1, Universitas Negeri Semarang.

Syamsuddin, Lukman. 2007. Manajemen Keuangan Perusahaan:Konsep Aplikasi Dalam Perencanaan, Pengawasan, dan Pengambilan Keputusan. Jakarta: Raja Grafindo Persada.
Sugiyono.2012. Metode Penelitian Kuantitatif Kualitatif dan $R \& D$. Bandung:Alfabeta.

Tjipto Darmadji dan Hendry $M$. Fakhruddin. 2001. Pasar Modal di Indonesia. Salemba Empat. Jakarta.

Tamba EGH, 2011, Pengaruh Struktur Kepemilikan Terhadap Pengungkapan Tanggung Jawab Sosial Perusahaan (Studi Empiris Pada Perusahaan Manufacturing Secondary Sectors yang Listing di BEI Tahun 2009), Universitas Diponegoro, Semarang.

Tarjo, 2008, Pengaruh Konsentrasi Kepemilikan Institusional dan Leverage Terhadap Laba, Nilai Pemegang Saham Serta Cost of Equity Capital; Simposium Nasional Akuntansi XI, Pontianak.

Wening, Kartikawati. 2009. Pengaruh Kepemilikan Institusional Terhadap Kinerja Keuangan Perusahaan. Jakarta.

Wahyudi, U., dan H. P. Pawestri. 2006. Implikasi Struktur Kepemilikan Terhadap Nilai Perusahaan: dengan Keputusan Keuangan sebagai Variabel Intervening. Simposium Nasional Akuntansi 9 Padang: 1-25

Wiagustini, Ni luh Putu. 2010. DasarDasar Manajemen Keuangan. Denpasar. Udayana University Press. Warapsari, Uccahati dan Suaryana, Agung. 2016. Pengaruh Kepemilikan Manajerial dan Institusional terhadap Nilai Perusahaan dengan Kebijakan Utangsebagai Variabel Intervening. E-Jurnal Akuntansi Vol.16.3. September (2016): 22882315.Universitas Udayana Bali. 